\title{
Mitigative effect of green tea extract against mercury(II) chloride toxicity in Allium cepa L. model
}

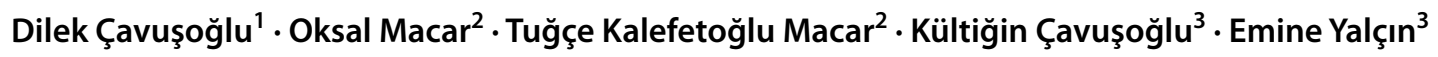

Received: 8 June 2021 / Accepted: 23 November 2021 / Published online: 4 January 2022

(c) The Author(s), under exclusive licence to Springer-Verlag GmbH Germany, part of Springer Nature 2021, corrected publication 2022

\begin{abstract}
Mercury $(\mathrm{Hg})$ is a highly toxic heavy metal for all organisms. In the present study, the mitigative role of $190 \mathrm{mg} / \mathrm{L}$ and $380 \mathrm{mg} / \mathrm{L}$ doses of green tea extract (GTex) against mercury(II) chloride $\left(\mathrm{HgCl}_{2}\right)$-induced toxicity was evaluated in Allium сера $\mathrm{L}$. For this aim, selected physiological, genotoxicity, and biochemical parameters as well as meristematic cell injuries in the roots were investigated. Ratios of catechin and caffeine in GTex were determined by HPLC analysis. Also, free radical scavenging activity of GTex was tested against superoxide and hydrogen peroxide radicals. As a result of $\mathrm{HgCI}_{2}$ application, germination percentage, root elongation, weight gain, and mitotic index (MI) declined, while the frequency of micronucleus $(\mathrm{MN})$, chromosomal abnormalities (CAs), and meristematic cell damages increased. $\mathrm{HgCI}_{2}$ administration also led to a significant increase in malondialdehyde content, superoxide dismutase, and catalase activities which are signs of oxidative stress. On contrary, applications of GTex together with $\mathrm{HgCI}_{2}$ reduced $\mathrm{HgCI}_{2}$-induced adverse effects in all parameters in a dose-dependent manner. Antioxidant components in GTex were listed as caffeine, epigallocatechin gallate, epigallocatechin, epicatechin gallate, and catechin according to their abundance. GTex exhibited a strong scavenging ability in the presence of superoxide and hydrogen peroxide radicals. The present study revealed the strong protective capacity of GTex against $\mathrm{HgCI}_{2}$-induced toxicity in $A$. cepa owing to its high antioxidant content with a multifaceted perspective. With this study, a reliable starting point was established for future studies investigating the more common and diverse use of GTex against toxic substances.
\end{abstract}

Keywords Allium cepa L. A Antioxidant $\cdot$ Genotoxicity $\cdot$ Green tea $\cdot \mathrm{HgCl}_{2} \cdot$ Oxidative stress

\section{Introduction}

Mercury $(\mathrm{Hg})$ and $\mathrm{Hg}$ compounds are used in many fields ranging from agriculture to medicine. Most of the Hg deposits of the world are in certain countries, including China, Kyrgyzstan, Mexico, Peru, Russia, Slovenia, Spain, and Ukraine, and are used in various industries (UNEP 2013).

Responsible Editor: Mohamed M. Abdel-Daim

Oksal Macar

oksal.macar@giresun.edu.tr

1 Department of Plant and Animal Production, Atabey Vocational High School, Isparta University of Applied Sciences, Isparta, Turkey

2 Department of Food Technology, Sebinkarahisar School of Applied Sciences, Giresun University, Giresun, Turkey

3 Department of Biology, Faculty of Science and Art, Giresun University, Giresun, Turkey
$\mathrm{Hg}$ is utilized in the electrical, cement, mining, paint, and paper industries. It is also a catalyst in plastic production, a component in various measurement and control devices such as barometers and thermometers, a filling material in dental treatments, and a fungicide in agriculture (Özbolat and Tuli 2016). Natural sources of $\mathrm{Hg}$ in the environment are soil and rocks. As a result of mining and various human activities, $\mathrm{Hg}$ compounds in rocks can be released and accumulate in high concentrations in soil or surface waters (Öztürk 2006). The increase in $\mathrm{Hg}$ contamination in nature with industrialization has tripled the $\mathrm{Hg}$ pollution in the environment. As a heavy metal, even small amounts of $\mathrm{Hg}$ can cause adverse effects on organisms including humans (Kamynsky et al. 2016). Hg toxicity varies depending on its chemical form. $\mathrm{Hg}$ exists in three forms: metallic, inorganic, and organic. Metallic $\mathrm{Hg}$ has a property that does not form a compound with other elements, is insoluble in water, and can evaporate in highly toxic amounts at room temperature. Inorganic $\mathrm{Hg}$ compounds, called mercury salts, are formed as a result of 
the combination of $\mathrm{Hg}$ with chlorine, sulfur, and oxygen. They are soluble in water and can introduce human body through direct contact and diet (Liu et al. 2021). Mercury(II) chloride $\left(\mathrm{HgCl}_{2}\right)$, one of the inorganic compounds of $\mathrm{Hg}$, has been classified as a "violent poison" (Kumari and Chand 2021). Organic $\mathrm{Hg}$, which is formed by the combination of $\mathrm{Hg}$ with the carbon atom, is the most toxic form and has a lipophilic character. Organic $\mathrm{Hg}$, which is formed by microorganisms such as Desulfovibrio desulfuricans and by various natural processes, is called methyl mercury and can also be obtained chemically by methylation of inorganic mercury (Akcan and Dursun 2008; Özbolat and Tuli 2016). Humans, aquatic organisms, and plants are open targets for $\mathrm{Hg}$ poisoning. The toxic effects of $\mathrm{Hg}$ in organisms are related to its high affinity for sulfhydryl groups. $\mathrm{Hg}$ is bound to macromolecules through sulfur with an oxidation state of -1 and -2 . In most cases, the binding sites are the thiol groups of the Cys residue in the macromolecule (Ajsuvakova et al. 2020). As a result of interaction between $\mathrm{Hg}$ and a macromolecule containing the -SH group, irreversible damage to the cell membrane, enzyme inhibition, impairment in transport mechanisms, and dysfunction in structural/functional proteins occur (Mutter et al. 2005; Zhu et al. 2021). Generally, Hg toxicity may increase neurological and neurodegenerative, metabolic, cardiovascular, and renal diseases while $\mathrm{Hg}$ in elemental form is especially harmful to the brain and kidneys (Ajsuvakova et al. 2020). Inorganic $\mathrm{Hg}$ forms are more accessible for plants than organic ones. Plants are contaminated with $\mathrm{Hg}$ as a result of irrigation with wastewater or $\mathrm{Hg}$-containing pesticide applications. In plants, $\mathrm{Hg}$ exhibits some toxic effects such as damage to the cell membrane and aquaporin, inhibition of light and dark reactions of photosynthesis, and root damage. Foods contaminated with $\mathrm{Hg}$, including edible parts of the plants, are the main routes of $\mathrm{Hg}$ exposure for humans (Natasha et al. 2020).

The toxic effects of heavy metals and many xenobiotics can be reduced by various antioxidant compounds. Green tea is a powerful antioxidant with a high content of catechins (Larsen et al. 2010; Bettuzzi et al. 2021). In green tea production, unlike black tea, Camellia sinensis L. leaves are dried and steamed to prevent fermentation (Cabrera et al. 2003). Research on the health benefits of tea has focused on green tea, as it contains more catechins than other types of tea (black and oolong). Green tea is particularly rich in flavonoids ( $30 \%$ by dry weight) including catechins and catechin derivatives. The most abundant catechins in green tea are (-)-epigallocatechin-3-gallate (EGCG) $(70 \%)$, epicatechin-3-gallate (ECG), and (-)-epigallocatechin (EGC) (Shirakami and Shimizu 2018). The main flavonols found in green tea are quercetin, kaempferol, and myricetin (Maiti et al. 2019). In addition, gallic acid, chlorogenic acid, neochlorogenic acid, and p-coumaryl quinic acid are frequent phenolic acids found in green tea (Şahin and Özdemir 2006).
These complex components contribute to many biological activities of green tea. Anticancer, antiatherosclerotic, antiobesity, antidiabetic, antibacterial, immunostimulatory, and anti-viral properties of green tea are mostly associated with these compounds (Suzuki et al. 2012; Hemmati et al. 2021). It was recently reported that EGCG extracted from green tea inhibits coronavirus replication (Jang et al. 2021).

As studies of toxic substances in humans raise ethical concerns, various plant, animal, and microbial analyses have been developed to assess toxicity and contamination (Xia et al. 2013). Allium assay, the most common plant experiment, reveals chromosomal damages in the meristem cells of the root of A. серa that resulted from genotoxicity of dangerous chemicals (Kaur et al. 2019). The Allium assay is wellaccepted for being cheap and simple as well as having highly correlated results with other assays (Özkara et al. 2015).

Determination of potential protectors against $\mathrm{Hg}$ poisoning is one of the important research topics. In this context, this work investigated whether the green tea extract (GTex) could mitigate damages caused by $\mathrm{HgCl}_{2}$ in growth (germination rate, root elongation, weight gain), genotoxicity (Mitotic index, chromosomal aberrations), biochemical parameters (malondialdehyde level, superoxide dismutase, and catalase activity), and meristematic cell damages of A. серa. Mercury-induced toxicity was examined with multiple parameters and the mitigative effect of GTex in each parameter was investigated. As the catechins in green tea are associated with antioxidant potential, the catechin content of GTex was analyzed by HPLC. The radical scavenging effect of GTEx was tested against strong oxidant superoxide and hydrogen peroxide $\left(\mathrm{H}_{2} \mathrm{O}_{2}\right)$. With these analyses, the toxicity of $\mathrm{HgCl}_{2}$ and the mitigative effects of GTEx were demonstrated with a versatile model.

\section{Materials and methods}

\section{Chemicals}

Among the forms of mercury, $\mathrm{HgCl}_{2}$ was used because of its water-soluble properties and also inorganic forms of mercury are more accessible to plants than organic ones. $\mathrm{HgCI}_{2}$ was obtained from Merck ( $\geq 99.5 \%$, CAS Number 7487-947). All standards and mobile phase solutions (purity: 99\%) of HPLC were obtained from Sigma-Aldrich. Pure green tea extract ( 60 capsules $\times 380 \mathrm{mg}$ ) was obtained commercially from Sepe Natural (İzmir/Turkey). Uniform and healthy small bulbs (A. cepa L., $2 \mathrm{n}=16$ ) used for the assay were obtained from Giresun, Turkey.

\section{Experimental design}

In this study, the protective feature of GTex against $\mathrm{HgCl}_{2}$ toxicity was investigated. Mercury toxicity and green tea 
Diagram 1. Experimental design of study

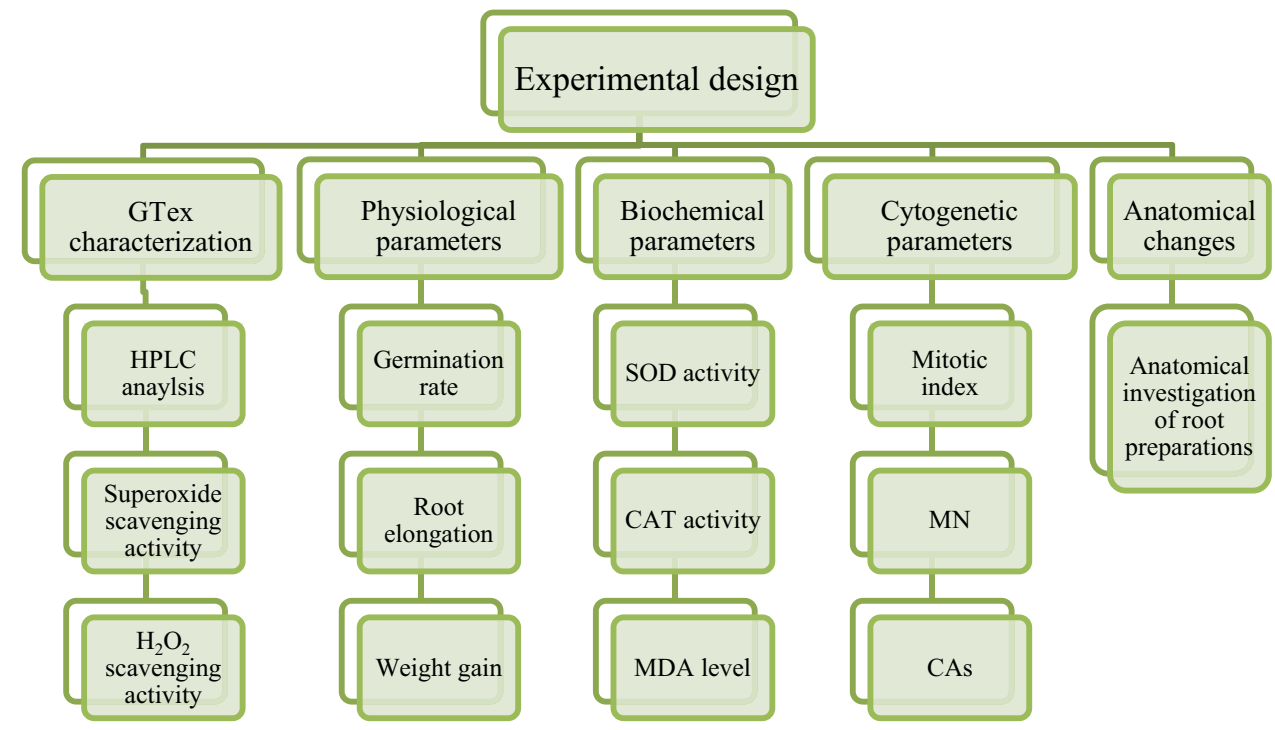

protection were investigated using physiological, cytogenetic, and biochemical parameters. The protective property of green tea is related to its phytochemical composition and radical scavenging activity. For this purpose, HPLC analysis and radical scavenging activity were also investigated. All parameters used in the study were given in Diagram 1.

\section{HPLC analysis}

GTex samples were extracted before HPLC analysis. For extraction, $1 \mathrm{~g}$ of sample was incubated with $150 \mathrm{~mL}$ of acetonitrile:water $(1: 1)$ for $40 \mathrm{~min}$ at $25^{\circ} \mathrm{C}$. The extract was filtered and then used for HPLC analysis (Agilent, 1260 Infinity series, RID) with an XDB-C8 analytical column (Zorbax Eclipse, $150 \mathrm{~mm} * 4.6 \mathrm{~mm}, 5 \mu \mathrm{m}$ ). The mobile phase consisting of water-acetonitrile-formic acid was used for HPLC analysis of GTex. Gradient elution program was applied for $20 \mathrm{~min}$ at a flow rate of $1 \mathrm{~mL} / \mathrm{min}$. Injection volume was $5.0 \mu \mathrm{L}$. Solutions of standard compounds such as epigallocatechin, epigallocatechin gallate, epicatechin gallate, catechin, and caffeine $(100 \mu \mathrm{g} / \mathrm{mL})$ were prepared in acetonitrile and stored at $4{ }^{\circ} \mathrm{C}$. All samples were microfiltered before injection (Fernandez et al. 2000).

\section{Radical scavenging activity of GTex}

Free radical scavenging is one of the important mechanisms of antioxidants. In this study, free radical scavenging activity of GTex was tested against superoxide and hydrogen peroxide.

The superoxide radical scavenging activity of GTex was studied according to the modified method proposed by Gülçin et al. (2010). Light induction of the reaction mixture was carried out using a fluorescent lamp $(20 \mathrm{~W})$. A mixture $(3 \mathrm{~mL})$ of riboflavin $\left(1.33 \times 10^{-5} \mathrm{M}\right)$, methionine $\left(4.46 \times 10^{-5} \mathrm{M}\right)$, and nitroblue tetrazolium $\left(8.15 \times 10^{-8} \mathrm{M}\right)$ was prepared and illuminated at $25{ }^{\circ} \mathrm{C}$ for $40 \mathrm{~min}$. The un-illuminated mixture was used as a blank. Different concentrations of GTex $(0.125-1.0 \mathrm{mg} / \mathrm{mL})$ were added to the reaction medium and the absorbance of all mixtures was measured at $560 \mathrm{~nm}$. The reduced absorption of the reaction mixture indicated the increased scavenging activity. The percentage of superoxide scavenging activity was calculated using Eq. 1.

Superoxide scavenging $(\%)=\left[1-\left(A_{1} / A_{2}\right)\right] \times 100$

$A_{1}$ is the absorbance of resveratrol or standard solution, and $A_{2}$ is the absorbance of the control. The experiment was repeated three times at each concentration.

$\mathrm{H}_{2} \mathrm{O}_{2}$ scavenging experiments were carried out according to the procedure of Ruch et al. (1989). A solution containing different concentrations of GTex $(3.4 \mathrm{~mL}, 0.125-1.0 \mathrm{mg}$ / $\mathrm{mL}$ ) and $0.6 \mathrm{~mL} \mathrm{H}_{2} \mathrm{O}_{2}(40 \mathrm{mM})$ was prepared. The absorbance of the reaction mixture was measured spectrophotometrically at $230 \mathrm{~nm} . \mathrm{H}_{2} \mathrm{O}_{2}$-free sodium phosphate buffer was accepted as blank. The scavenging activity was determined by monitoring the decrease in $\mathrm{H}_{2} \mathrm{O}_{2}$ absorbance. The absorbance of $\mathrm{H}_{2} \mathrm{O}_{2}$ and the scavenging activity of resveratrol were calculated using Eqs. 2 and 3, respectively.

$\operatorname{Absorbance}\left(\lambda_{230}\right)=0.505 \times\left[\mathrm{H}_{2} \mathrm{O}_{2}\right]$

$\mathrm{H}_{2} \mathrm{O}_{2}$ scavenging activity $(\%)=\left[1-\left(A_{1} / A_{2}\right)\right] \times 100$

$A_{1}$ is the absorbance of solution in the presence of GTex, and $A_{2}$ is the absorbance of the control.

Butylated hydroxytoluene (BHT) was used as a standard antioxidant agent. 


\section{Germination and physiological parameters}

Equal-sized $(4.7 \pm 0.1 \mathrm{~g})$ and healthy A. cepa bulbs were sterilized using $\mathrm{NaClO}(2.5 \%)$ solution for $10 \mathrm{~min}$ and then rinsed with distilled water. The bulbs of A. cepa were divided into six treatment groups and immersed in the prepared solutions in glass beakers: Control-Tap water, $190 \mathrm{mg} / \mathrm{L}$ GTex, $380 \mathrm{mg} / \mathrm{L}$ GTex, 100 mg/L HgCI, $190 \mathrm{mg} / \mathrm{L} \mathrm{GTex}+100 \mathrm{mg} / \mathrm{L} \mathrm{HgCI}{ }_{2}$, and $380 \mathrm{mg} / \mathrm{L} \mathrm{GTex}+100 \mathrm{mg} / \mathrm{L} \mathrm{HgCI}{ }_{2}$. All solutions were prepared in $\mathrm{dH}_{2} \mathrm{O}$. Bulbs were germinated at $23{ }^{\circ} \mathrm{C}$ in dark for $72 \mathrm{~h}$. At the end of the $72^{\text {nd }}$ hour, germination periods were ended, and then germination rates were calculated using 50 bulbs $(n=50)$. $\mathrm{HgCI}_{2}$ dosage was determined by considering our previous studies (Çavuşoğlu et al. 2018). The applied GTex concentration was chosen as a value above the dose at which the protective effect was observed in Allium cells (Çavuşoğlu 2020). A millimetric ruler was used to measure the root lengths of 10 bulbs $(n=10)$. The mean difference in weights before and after germination was measured with precision scales over 10 bulbs $(n=10)$.

\section{Cytogenetic parameters}

Root tips of $(1-1.5 \mathrm{~cm})$ A. cepa bulbs were used for cytogenetic analysis. Root tips were pretreated with saturated paradichlorobenzene solution for $4 \mathrm{~h}$ and then fixed for a day in solution of ethanol-acetic acid (75-25\%). Fixated tips were hydrolyzed using $1 \mathrm{~N} \mathrm{HCl}$ at $60{ }^{\circ} \mathrm{C}$ for $17 \mathrm{~min}$ before stained with Feulgen for 1.5-2 h. To prepare squash slides, stained root tips were crushed with a drop of $45 \%$ acetic acid (Sharma and Gupta 1982). Mitotic index (MI), frequencies of micronucleus (MN), and chromosomal abnormalities (CAs) were observed at $500 \times$ magnification with a microscope (Olympus CX41) and photographed with a digital camera (Olympus C-5060). MI was calculated by analyzing 1,000 of cells from ten slides prepared from each treatment $(10,000$ for each treatment). CAs and $\mathrm{MN}$ frequencies of each treatment were observed on ten slides ( 1,000 cells for each treatment) (Çavuşoğlu et al. 2021).

\section{Antioxidant/oxidant dynamics}

\section{Lipid peroxidation}

MDA levels of A. cepa roots were determined as an indicator of lipid peroxidation in cells. Lipid peroxidation experiment was conducted according to the method suggested by Unyayar et al. (2006). Root tissue $(0.5 \mathrm{~g})$ was homogenized in the presence of $1 \mathrm{ml}$ of $5 \%$ trichloroacetic acid (TCA) solution. The homogenates of samples were centrifuged at $12,000 \mathrm{rpm}$ for $15 \mathrm{~min}$ at room temperature. Equal volumes of $0.5 \%$ thiobarbituric acid (TBA), TCA (20\%), and supernatant were mixed in a glass tube and incubated at boiling hot bath $\left(98{ }^{\circ} \mathrm{C}\right)$ for $30 \mathrm{~min}$. At the end of $30 \mathrm{~min}$, the mixture tubes were transferred to an ice-cold bath to stop the reaction. Cooled mixtures were centrifuged at $10,000 \mathrm{rpm}$ for $5 \mathrm{~min}$. The absorbance of the mixtures was read at $532 \mathrm{~nm}$ on a spectrophotometer.

\section{Antioxidant enzymes}

SOD and CAT activities were measured to understand the oxidative stress levels of root samples. SOD and CAT activity assays were performed using the same extraction methods. $0.5 \mathrm{~g}$ of fresh root material from sample was homogenized in the presence of $5 \mathrm{~mL}$ sodium phosphate buffer $(\mathrm{pH} 7.8)$. The collected homogenates were centrifuged at $10,500 \mathrm{rpm}$ for 20 min at $4{ }^{\circ} \mathrm{C}$ and their supernatants were used for SOD and CAT enzyme analysis (Çavuşoğlu et al. 2021).

Activity of SOD was determined using the method proposed by Beauchamp and Fridovich (1971). To obtain a reaction solution, $0.01 \mathrm{~mL}$ extract was added to a mixture containing $1.5 \mathrm{~mL}$ sodium phosphate buffer $(0.05 \mathrm{M}, \mathrm{pH}$ 7.8), $0.28 \mathrm{~mL}$ deionized water, $0.3 \mathrm{~mL}$ nitroblue tetrazolium chloride, $0.3 \mathrm{~mL}$ methionine, $0.3 \mathrm{~mL}$ EDTA- $\mathrm{Na}_{2}, 0.3 \mathrm{~mL}$ riboflavin, and $0.01 \mathrm{~mL} 4 \%$ insoluble polyvinylpyrrolidone. A $215 \mathrm{~W}$ fluorescent lamp was used to start the reaction in glass tubes. At the end of the $10^{\text {th }}$ minute, absorbance of the reaction mixture reaction was measured at $560 \mathrm{~nm}$.

Activity of CAT was measured using the modified method of Beers and Sizer (1952). To prepare a reaction mixture, $1.5 \mathrm{~mL}$ of $200 \mathrm{mM}$ sodium phosphate buffer $(\mathrm{pH}$ 7.8), $0.3 \mathrm{~mL}$ of $0.1 \mathrm{M} \mathrm{H}_{2} \mathrm{O}_{2}$, and $1.0 \mathrm{~mL}$ of distilled water were mixed in a glass tube. Addition of $0.2 \mathrm{~mL}$ sample extract to the mixture initiated the reaction. CAT activity was measured by monitoring the reduction in absorbance at $240 \mathrm{~nm}$ as a result of $\mathrm{H}_{2} \mathrm{O}_{2}$ consumption. Activity was expressed as $\mathrm{OD}_{240} \mathrm{~nm} \mathrm{~min}^{-1} \mathrm{FW}$. MDA, SOD, and CAT assays were repeated three times and performed in triplicate.

\section{Anatomical alterations}

Root tips were investigated for $\mathrm{HgCI}_{2}$-induced anatomical alterations in meristematic cells. Before cross-sections were taken manually, root tips were thoroughly rinsed with distilled water to remove residues. Cross-sections were stained with a drop of $1 \%$ methylene blue. Meristematic damages were observed at $500 \times$ magnification with a light microscope (Olympus CX41 with Olympus C-5060 digital camera). Meristematic cell damages were classified as no damage, little damage, moderate damage, and severe damage (Yalçın et al. 2021).

\section{Statistical analyses}

The statistical analyses of results were performed using SPSS (version 23) software (SPSS Inc., Chicago, IL, USA). 
Fig. 1 HPLC chromatogram and the contents $(\% \mathrm{w} / \mathrm{w}$, dry base) of GTex. a Epigallocatechin, $\mathbf{b}$ catechin, $\mathbf{c}$ caffeine, d epigallocatechin gallate, $\mathbf{e}$ epicatechin gallate

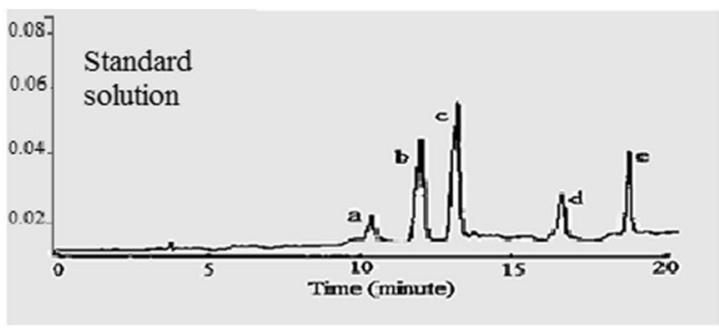

\section{- Caffeine \\ - Epigallocatechin gallate \\ Epigallocatechin \\ Epicatechin gallate \\ Catechin}

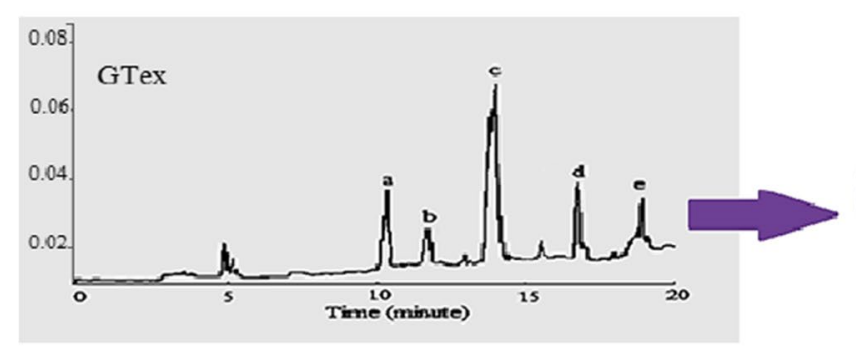

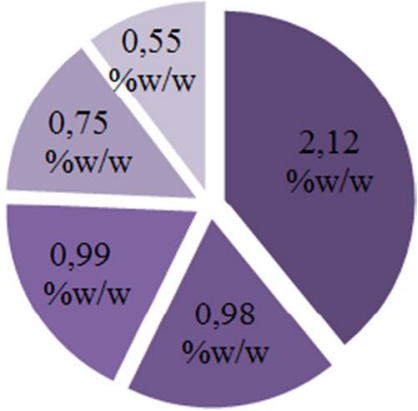

Data were shown as mean \pm standard deviation (SD). The statistical significance between the means was assessed using One-way ANOVA (one-way analysis of variance) and Duncan tests, and it was considered statistically significant when the determined value $(p)$ was less than 0.05 .

\section{Results and discussion}

\section{HPLC analysis of GTex}

The presence of different ratios of catechin and caffeine in GTex was determined by HPLC analysis and the chromatogram was given in Fig. 1. In GTex, catechin species were found in the range of $0.559-0.991 \%(\mathrm{w} / \mathrm{w})$, while caffeine was detected at a rate of $2.12 \%(\mathrm{w} / \mathrm{w})$. Among the catechins, epigallocatechin gallate and epigallaocatechin were found in higher proportion compared to others. Catechins showed an order according to their presence in GTex as epigallocatechin gallate $>$ epigallocatechin $>$ epicatechin gallate $>$ catechin. It has also been found that there is a higher rate of caffeine in GTex compared to catechins. Fernandez et al. (2000) reported that the proportions of epigallocatechin gallate, epigallocatechin, and catechin in a commercially available green tea extract were $4.6 \%, 2.25 \%$, and $0.55 \%(\mathrm{w} / \mathrm{w})$, respectively. Catechins are antioxidant molecules capable of scavenging reactive oxygen species and reactive nitrogen species. Tea catechins are known to protect $\mathrm{GSH}$, a powerful endogenous antioxidant, against oxidation. The relative efficiency of catechins in terms of GSH protection is ranked as epigallocatechin gallate $>$ epigallocatechin $>$ epicatechin gallate $>$ epicatechin (Maurya and Rizvi 2009). Shirakami and Shimizu (2018) reported that the most biologically active member of tea catechines is epigallocatechin gallate due to its suppressive effects against carcinogenesis. The high epigallocatechin gallate and epigallocatechin contents of GTex, as proved by HPLC analysis, show that GTex has an important role in the protection of endogenous antioxidants in cells.

\section{Radical scavenging activity of GTex}

There is a close relationship between the protective role of GTex and its antioxidant activity. Radical scavenging activity plays an important role in antioxidant activity mechanism. The radical scavenging property of GTex was tested against superoxide and $\mathrm{H}_{2} \mathrm{O}_{2}$ and the results were given in Fig. 2 . Superoxide and $\mathrm{H}_{2} \mathrm{O}_{2}$ scavenging effects of GTex and BHT increased with the increasing concentrations of the solutions. Superoxide scavenging activities of $1 \mathrm{mg} / \mathrm{mL}$ GTex and BHT were found as $79 \%$ and $63.1 \%$, respectively. There were statistically significant differences in superoxide removal activities of GTex and BHT at all tested concentrations except for the $0.25 \mathrm{mg} / \mathrm{mL}$ concentration $(p<0.05)$. The maximum hydrogen peroxide removal activities of GTex and BHT were 71\% and $89 \%$, respectively. There were statistically significant differences in $\mathrm{H}_{2} \mathrm{O}_{2}$ radical scavenging activities of GTex and BHT at all tested concentrations $(p<0.05)$.

These results indicated that GTex is a powerful antioxidant and would have protective properties against induced oxidative stress. The HPLC analysis performed in this study showed that GTex contains high levels of catechins and that the high radical scavenging effect of GTex is directly related to these catechins. Catechins have the ability to inhibit free radical formation, scavenge free radicals, and chelate transition metal ions, which are catalysts of free radical reactions. In addition, catechins scavenge free radicals such as hydroxyl, superoxide, and lipid radicals (Costa et al. 2007). It is stated in the literature that GTex is a good radical scavenging agent (Masek et al. 2017). Gramza et al. (2005) 

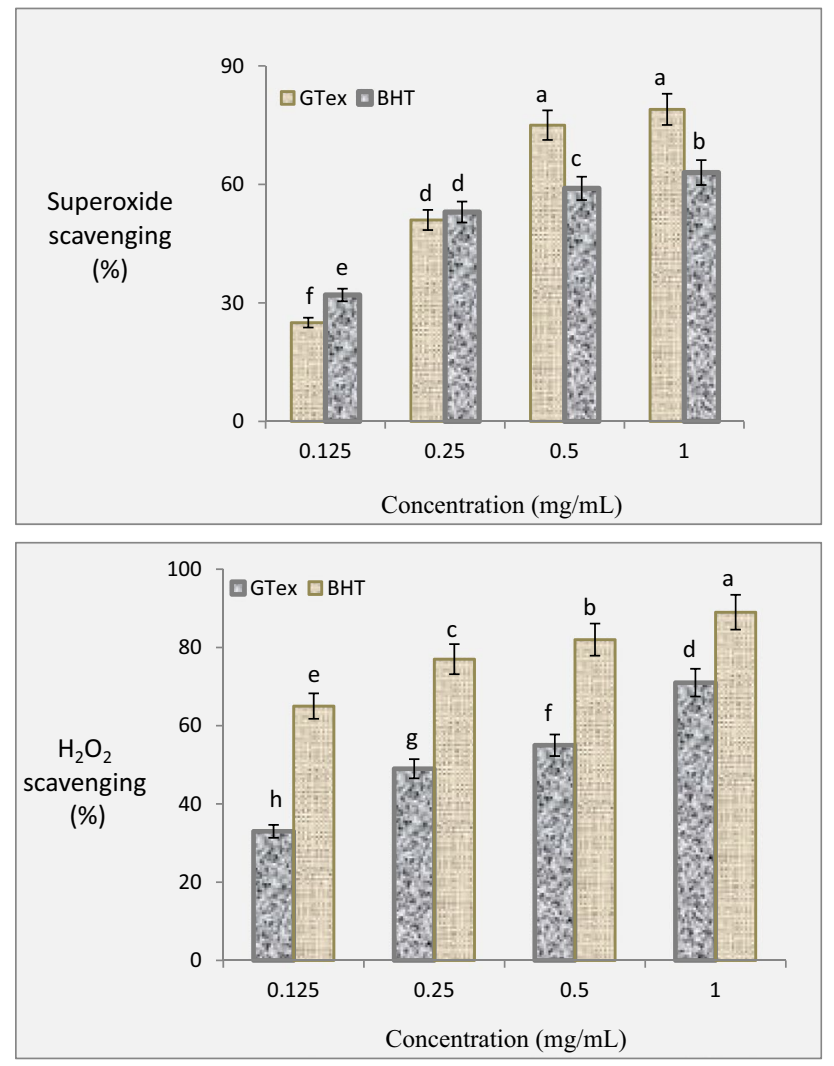

Fig. 2 Superoxide and $\mathrm{H}_{2} \mathrm{O}_{2}$ scavenging property of GTex and BHT. Each histogram is a decimal average. The vertical lines on the bars indicate the standard deviation. Different letters ${ }^{(\mathrm{a}-\mathrm{h})}$ indicated averages $p<0.05$ are significant

reported that green tea and green tea polyphenols have a much stronger scavenging effect on active oxygen radicals than vitamin $\mathrm{C}$ and vitamin $\mathrm{E}$.

\section{Germination and physiological parameters}

Effects of $\mathrm{HgCI}_{2}$ and GTex on physiological parameters of $A$. cepa during germination are shown in Table 1. Administration of $190 \mathrm{mg} / \mathrm{L}$ and $380 \mathrm{mg} / \mathrm{L}$ GTex did not cause a statistically significant change in germination rate, root elongation, and weight gain in A. cepa bulbs ( $p>0.05)$. Absence of difference in physiological parameters in physiological parameters can be interpreted as GTex has no toxic effect on $A$. cepa bulbs during germination. Application of on $100 \mathrm{mg} / \mathrm{L}$ $\mathrm{HgCI}_{2}$ resulted in significant reduction in root elongation $(75 \%)$ and weight gain $(82 \%)(p<0.05)$ as well apparent drop in germination rate (52\%) compared to control. Adverse effect of mercurials on plant germination period documented on several plants (Patra and Sharma 2000; Muhammad et al. 2015). Similar to our results, Çavuşoğlu et al. (2018) reported depressive effects of $\mathrm{HgCI}_{2}$ on germination percentage, weight gain, and root length of A. cepa bulbs. Patra and Sharma (2000) stated that $\mathrm{Hg}$ effects the embryo by causing -S-Hg-S- bridge formation and effecting -SH system in cells. -SH system disruption causes more destructive consequences in the embryo than other tissues due to its high -SH content (Patra and Sharma 2000). Mercury is bound to macromolecules through sulfur with an oxidation state of -1 and -2 . In most cases, the binding sites are the thiol groups of the Cys residue in the macromolecule (Ajsuvakova et al. 2020). Modification of thiol groups in proteins can cause serious functional damage in biological systems, including loss of enzyme activity. Reduced root elongation and weight gain showed severe damage on germinated $A$. cepa bulbs due to - $\mathrm{SH}$ degradation caused by $\mathrm{HgCl}_{2}$ administration. It should be considered that $\mathrm{Hg}$-induced oxidative stress is associated with the interaction between $\mathrm{Hg}$ and - $\mathrm{SH}$ groups and is equally important in the terms of toxicity (Hansen et al. 2006). Administration of increasing GTex doses (190 mg/L and $380 \mathrm{mg} / \mathrm{L}$ GTex) with $100 \mathrm{mg} / \mathrm{L}$ $\mathrm{HgCl}_{2}$ significantly reduced the adverse effect of $\mathrm{HgCl}_{2}$ on the selected physiological parameters of $A$. cepa depending on the dose, but their physiological parameter results were still below control levels. The best reducing effect against $\mathrm{Hg}$ toxicity was observed in $380 \mathrm{mg} / \mathrm{L} \mathrm{GTex}+100 \mathrm{mg} / \mathrm{L} \mathrm{HgCl}$ application with $22 \%$ reduction in germination rate, $34 \%$ reduction in root elongation, and $44 \%$ reduction in weight gain compared to control. GTex doses mitigated $\mathrm{HgCl}_{2}$ induced toxicity in germination process. Many experimental studies in the literature indicate that plant extracts, including tea, can alleviate experimentally induced $\mathrm{Hg}$ toxicity
Table 1 Effects of $\mathrm{HgCI}_{2}$ and GTex on physiological parameters

\begin{tabular}{llll}
\hline Treatments & $\begin{array}{l}\text { Germination rate } \\
(\%)\end{array}$ & Root elongation $(\mathrm{cm})$ & Weight gain $(\mathrm{g})$ \\
\hline Control & 96 & $9.50 \pm 1.70^{\mathrm{a}}$ & $+6.30^{\mathrm{a}}$ \\
$190 \mathrm{mg} / \mathrm{L} \mathrm{GTex}$ & 98 & $9.60 \pm 1.74^{\mathrm{a}}$ & $+6.41^{\mathrm{a}}$ \\
$380 \mathrm{mg} / \mathrm{L} \mathrm{GTex}$ & 98 & $9.70 \pm 1.75^{\mathrm{a}}$ & $+6.48^{\mathrm{a}}$ \\
$100 \mathrm{mg} / \mathrm{L} \mathrm{HgCI}$ & 44 & $2.40 \pm 0.96^{\mathrm{d}}$ & $+0.50^{\mathrm{d}}$ \\
$190 \mathrm{mg} / \mathrm{L} \mathrm{GTex}+100 \mathrm{mg} / \mathrm{L} \mathrm{HgCI}{ }_{2}$ & 60 & $4.10 \pm 1.38^{\mathrm{c}}$ & $+1.85^{\mathrm{c}}$ \\
$380 \mathrm{mg} / \mathrm{L} \mathrm{GTex}+100 \mathrm{mg} / \mathrm{L} \mathrm{HgCI}{ }_{2}$ & 75 & $6.30 \pm 1.55^{\mathrm{b}}$ & $+3.50^{\mathrm{b}}$ \\
\hline
\end{tabular}

*Means with the same letter within the same column are not statistically different $(p>0.05)$ 
Fig. 3 Normal mitosis phases in meristems of A. cepa root tip cells (a interphase, b prophase, $\mathbf{c}$ metaphase $2 \mathrm{n}=16, \mathbf{d}$ anaphase, e telophase. Scale bar $=10 \mu \mathrm{m})$

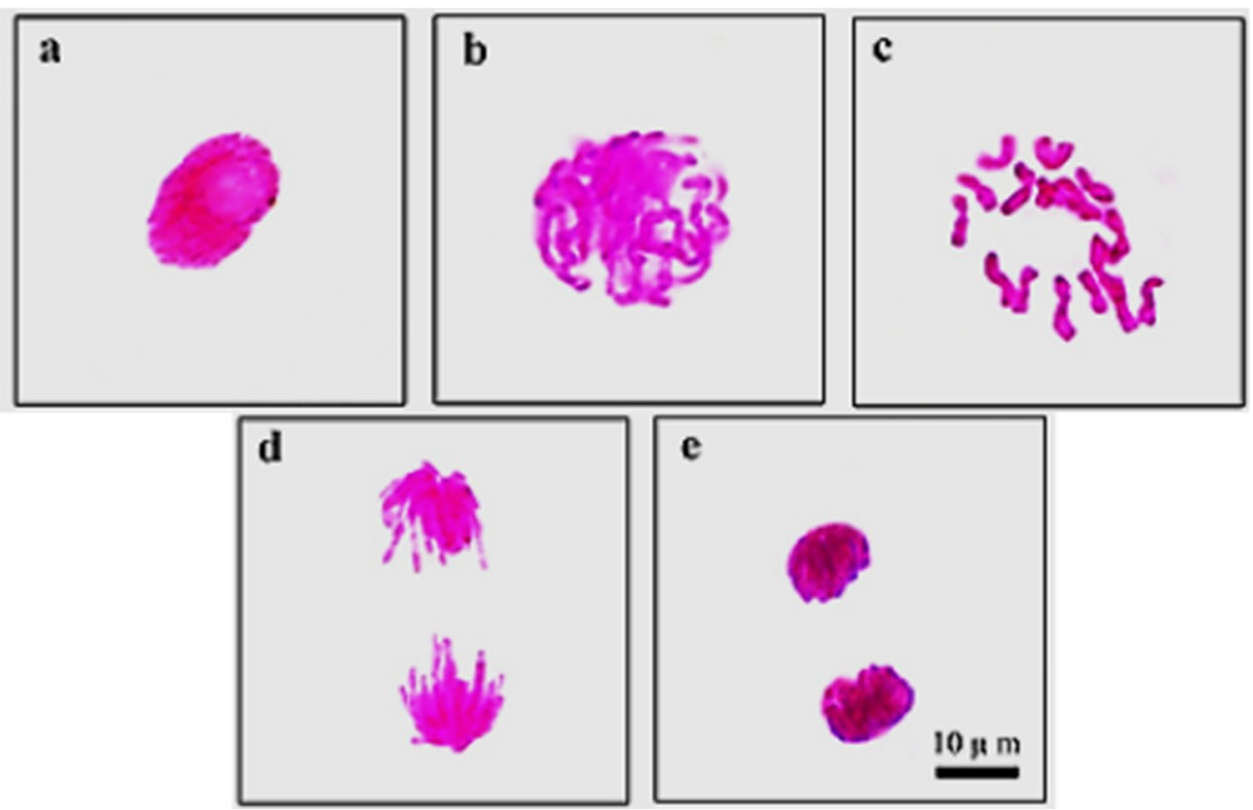

in animals (Bhattacharya 2018). In contrast, there is no previous study on the role of GTex in protecting against $\mathrm{Hg}$ toxicity in plants. Studies on plant extracts and heavy metals in A. cepa indicated that the protective roles of plant extracts were related to their antioxidant capacity (Glińska et al. 2007; Macar et al. 2020a; Kalefetoğlu Macar et al. 2020a). Similarly, the protective property of GTex against mercury is also associated with its antioxidant activity. Mercury acts by inhibiting antioxidants containing - $\mathrm{SH}$ such as glutathione, while green tea improves the deteriorated antioxidant balance of the cell. Furthermore, GTEx also has a protective role on -SH groups in molecules. Miyagawa et al. (1997) reported that GTex and tea polyphenols play an important role in the inhibition of the loss of thiol groups in molecules. Especially catechin and its derivatives in green tea not only exhibit strong antioxidant properties in vitro, but also modulate the activity of antioxidant defense enzymes such as superoxide dismutase (SOD), glutathione peroxidase (GPx), and catalase (CAT). In this way, they mediate the recovery of the antioxidant balance disrupted by mercury (Simos et al. 2012).

\section{Cytogenetic parameters}

Normal appearance of mitotic phases in root tips of control group is presented in Fig. 3. Effects of GTex and $\mathrm{HgCI}_{2}$ on MI, MN, and CAs are shown in Table 2 and Fig. 4. Similar to physiological parameters, application of $190 \mathrm{mg} / \mathrm{L}$ and $380 \mathrm{mg} / \mathrm{L}$ GTex did not induce statistical changes on the frequencies of MI, MN, and CAs. MI measures the proportion of cells in the mitosis phase and is a common indicator of cell proliferation (Jaiswal et al. 2021). MI results of GTex exposed bulbs revealed that GTex did not hinder cell mitosis as a toxic substance. GTex also did not increase incidences of MN (Fig. 4a) and CAs which are reliable biomarkers of genotoxicity (Grant 1982). In contrast to the effects of GTex, administration of $100 \mathrm{mg} / \mathrm{L} \mathrm{HgCl}$ resulted in a statistically significant decrease in MI (43\%) and a sudden increase in the frequencies of $\mathrm{MN}(54.4 \pm 5.83)$ and CAs compared to control $(p<0.05)$. In the presence of $\mathrm{HgCl}_{2}$, fragment (Fig. $4 \mathrm{~b}$, c) formation $(40.2 \pm 4.85)$ was the most observed CAs followed by sticky chromosomes (Fig. 4d) $(35.7 \pm 3.24)$ and vagrant chromosomes (Fig. 4e, f) $(28.5 \pm 3.12)(p<0.05)$. Bridge formation (Fig. 4f), unequal distribution of chromatin (Fig. 4g), irregular mitosis (Fig. 3h), and nucleus damage (Fig. 4i) were also observed as a result of $\mathrm{HgCl}_{2}$ exposure. These results provided strong evidence for $\mathrm{Hg}$ toxicity. In line with our results, the reduction of mitotic index and induction of CAs in A. cepa caused by $\mathrm{Hg}$ treatment were previously reported (Patra et al. 2004; Sharma et al. 2012; Çavuşoğlu et al. 2018). In addition, Çavuşoğlu et al. (2018) also mentioned that the most common $\mathrm{Hg}$-induced CAs in A. cepa were $\mathrm{MN}$, fragment formation, and sticky chromosomes. Crespo-López et al. (2009) explained the genotoxic effect of $\mathrm{Hg}$ with oxidative stress caused by free radical and reactive oxygen species (ROS) formation caused by $\mathrm{Hg}$. Although the main reason of $\mathrm{Hg}$ genotoxicity is oxidative stress, adverse effects of $\mathrm{Hg}$ on microtubules, DNA repair mechanism, and DNA (directly) are also important in genotoxicity (Crespo-López et al. 2009). Briefly, the genotoxic effect of mercury is attributed to its ability to bind to the sulfhydryl groups of tubulin, impairing spindle function, causing chromosomal aberrations and polyploidy. Another important mechanism of mercury genotoxicity is its ability 
Table 2 Effects of GTex and $\mathrm{HgCI}_{2}$ on genotoxicity parameters

\begin{tabular}{lllllll}
\hline CAs & Control & $190 \mathrm{mg} / \mathrm{L} \mathrm{GTex}$ & $380 \mathrm{mg} / \mathrm{L} \mathrm{GTex}$ & $100 \mathrm{mg} / \mathrm{L} \mathrm{HgCI} \mathrm{H}_{2}$ & $\begin{array}{l}190 \mathrm{mg} / \mathrm{L} \\
\mathrm{Gtex}+100 \mathrm{mg} / \mathrm{L} \\
\mathrm{HgCl}_{2}\end{array}$ & $\begin{array}{l}380 \mathrm{mg} / \mathrm{L} \\
\mathrm{Gtex}+100 \mathrm{mg} / \mathrm{L} \\
\mathrm{HgCI}_{2}\end{array}$ \\
\hline MI & $851 \pm 30.5^{\mathrm{a}}$ & $864 \pm 32.6^{\mathrm{a}}$ & $871 \pm 34.5^{\mathrm{a}}$ & $485 \pm 20.4^{\mathrm{d}}$ & $551 \pm 24.8^{\mathrm{c}}$ & $691 \pm 27.6^{\mathrm{b}}$ \\
MN & $0.26 \pm 0.32^{\mathrm{d}}$ & $0.16 \pm 0.24^{\mathrm{d}}$ & $0.10 \pm 0.15^{\mathrm{d}}$ & $54.4 \pm 5.83^{\mathrm{a}}$ & $40.1 \pm 4.36^{\mathrm{b}}$ & $31.5 \pm 3.98^{\mathrm{c}}$ \\
FRG & $0.00 \pm 0.00^{\mathrm{d}}$ & $0.00 \pm 0.00^{\mathrm{d}}$ & $0.00 \pm 0.00^{\mathrm{d}}$ & $40.2 \pm 4.85^{\mathrm{a}}$ & $32.3 \pm 3.95^{\mathrm{b}}$ & $25.6 \pm 3.14^{\mathrm{c}}$ \\
SC & $0.24 \pm 0.34^{\mathrm{d}}$ & $0.13 \pm 0.22^{\mathrm{d}}$ & $0.00 \pm 0.00^{\mathrm{d}}$ & $35.7 \pm 3.24^{\mathrm{a}}$ & $25.8 \pm 2.96^{\mathrm{b}}$ & $18.7 \pm 2.38^{\mathrm{c}}$ \\
VC & $0.00 \pm 0.00^{\mathrm{d}}$ & $0.00 \pm 0.00^{\mathrm{d}}$ & $0.00 \pm 0.00^{\mathrm{d}}$ & $28.5 \pm 3.12^{\mathrm{a}}$ & $21.9 \pm 2.85^{\mathrm{b}}$ & $14.6 \pm 2.23^{\mathrm{c}}$ \\
B & $0.00 \pm 0.00^{\mathrm{d}}$ & $0.00 \pm 0.00^{\mathrm{d}}$ & $0.00 \pm 0.00^{\mathrm{d}}$ & $24.3 \pm 2.52^{\mathrm{a}}$ & $15.2 \pm 1.80^{\mathrm{b}}$ & $9.60 \pm 1.45^{\mathrm{c}}$ \\
UDC & $0.00 \pm 0.00^{\mathrm{d}}$ & $0.00 \pm 0.00^{\mathrm{d}}$ & $0.00 \pm 0.00^{\mathrm{d}}$ & $18.8 \pm 1.53^{\mathrm{a}}$ & $10.4 \pm 1.12^{\mathrm{b}}$ & $6.60 \pm 0.92^{\mathrm{c}}$ \\
IM & $0.18 \pm 0.24^{\mathrm{d}}$ & $0.00 \pm 0.00^{\mathrm{d}}$ & $0.00 \pm 0.00^{\mathrm{d}}$ & $15.1 \pm 1.24^{\mathrm{a}}$ & $8.70 \pm 0.91^{\mathrm{b}}$ & $4.30 \pm 0.66^{\mathrm{c}}$ \\
ND & $0.00 \pm 0.00^{\mathrm{d}}$ & $0.00 \pm 0.00^{\mathrm{d}}$ & $0.00 \pm 0.00^{\mathrm{d}}$ & $5.00 \pm 0.84^{\mathrm{a}}$ & $3.10 \pm 0.69^{\mathrm{b}}$ & $1.50 \pm 0.52^{\mathrm{c}}$ \\
\hline
\end{tabular}

*Means with the same letter within the same line are not statistically different $(p>0.05)$. MI, mitotic index; $M N$, micronucleus; $F R G$, fragment; $S C$, sticky chromosome; $V C$, vagrant chromosome; $B$, bridge; $U D C$, unequal distribution of chromatin; $I M$, irregular mitosis; $N D$, nucleus damage

to produce free radicals that can cause DNA damage (Telahigue et al. 2020).

Parallel to physiological parameters, administration of $190 \mathrm{mg} / \mathrm{L}$ and $380 \mathrm{mg} / \mathrm{L}$ GTex doses with $100 \mathrm{mg} / \mathrm{L} \mathrm{HgCl}{ }_{2}$ restored the genotoxic effects of $\mathrm{Hg}$ in a dose depending manner. The MI level was restored to $81 \%$ of the control in the $380 \mathrm{mg} / \mathrm{L}$ GTex application with $\mathrm{Hg}$, and $65 \%$ in the $190 \mathrm{mg} / \mathrm{L}$ GTex application with $\mathrm{Hg}(p<0.05)$. Hginduced MN frequencies also decreased with the $190 \mathrm{mg} / \mathrm{L}$ $(40.1 \pm 4.36)$ and $380 \mathrm{mg} / \mathrm{L}(31.5 \pm 3.98)$ GTex application given with $\mathrm{Hg}(p<0.05)$. All CAs resulting from $\mathrm{Hg}$ treatment declined with increased GTex administration $(p<0.05)$. Although the levels in control had not been reached, the application of GTex had a significant mitigating power on the adverse effects of the $\mathrm{Hg}$ on the genotoxicity parameters. Our findings regarding the antigenotoxic properties of GTex were consistent with previous studies based on different test systems such as Chinese hamster V-79 (Roy et al. 2003), mice (García-Rodríguez et al. 2013), and human leucocytes (Glei and Pool-Zobel 2006; Jo et al. 2008). The main focus of these studies was on catechins and polyphenols, powerful antioxidants found in abundance in green tea.
Hasegawa et al. (1995) noted that the rich antioxidant content of tea prevented induction of DNA damage and DNA scission from genotoxic agents. $\mathrm{Hg}$-induced genotoxicity might be alleviated by GTex preventing the formation of free radicals or facilitating their scavenging. GTex reduces the genotoxic effects by reducing free radicals and protecting thiol groups and also has a positive effect on the DNA repair mechanism. Chong et al. (2019) reported that GTex enhances expression of DNA repair genes in yeast cells.

\section{Antioxidant/oxidant dynamics}

Oxidative stress related to $\mathrm{HgCI}_{2}$ and GTex applications in A. cepa was investigated using MDA level, SOD, and CAT activity analyses (Table 3). Applications of $190 \mathrm{mg} / \mathrm{L}$ and $390 \mathrm{mg} / \mathrm{L}$ GTex did not induce a significant change in MDA levels as well as SOD and CAT activities compared to control in A. cepa root tissue. In contrast, $\mathrm{HgCl}_{2}$ treatment significantly increased MDA level (2.7 times), SOD activity ( 2 times), and CAT activity (2.9 times) compared to control $(p<0.05)$. On the other hand, co-administration of increasing GTex doses with $\mathrm{HgCl}_{2}$ significantly reduced SOD and
Table 3 Effect of $\mathrm{HgCI}_{2}$ and GTex on biochemical parameters

\begin{tabular}{llll}
\hline Treatments & MDA $\left(\mu \mathrm{M} \mathrm{g}^{-1} \mathrm{FW}\right)$ & SOD $\left(\mathrm{U} \mathrm{mg}^{-1} \mathrm{FW}\right)$ & $\begin{array}{l}\mathrm{KAT} \\
\left(\mathrm{OD}_{240 \mathrm{~nm}}\right. \\
\left.\mathrm{min}^{-1} \mathrm{FW}\right)\end{array}$ \\
\hline Control & $2.70 \pm 1.48^{\mathrm{d}}$ & $66.8 \pm 5.32^{\mathrm{d}}$ & $0.92 \pm 1.15^{\mathrm{d}}$ \\
$190 \mathrm{mg} / \mathrm{L} \mathrm{GTex}$ & $2.60 \pm 1.45^{\mathrm{d}}$ & $64.1 \pm 5.19^{\mathrm{d}}$ & $0.88 \pm 1.12^{\mathrm{d}}$ \\
$380 \mathrm{mg} / \mathrm{L} \mathrm{GTex}$ & $2.50 \pm 1.42^{\mathrm{d}}$ & $65.3 \pm 5.24^{\mathrm{d}}$ & $0.87 \pm 1.10^{\mathrm{d}}$ \\
$100 \mathrm{mg} / \mathrm{L} \mathrm{HgCI}$ & & $135 \pm 9.16^{\mathrm{a}}$ & $2.68 \pm 1.60^{\mathrm{a}}$ \\
$190 \mathrm{mg} / \mathrm{L} \mathrm{GTex}+100 \mathrm{mg} / \mathrm{L} \mathrm{HgCI}{ }_{2}$ & $7.30 \pm 1.62^{\mathrm{b}}$ & $110 \pm 8.25^{\mathrm{b}}$ & $2.20 \pm 1.48^{\mathrm{b}}$ \\
$380 \mathrm{mg} / \mathrm{L} \mathrm{GTex}+100 \mathrm{mg} / \mathrm{L} \mathrm{HgCI}{ }_{2}$ & $5.00 \pm 1.48^{\mathrm{c}}$ & $92.4 \pm 6.58^{\mathrm{c}}$ & $1.83 \pm 1.30^{\mathrm{c}}$ \\
\hline
\end{tabular}

*Means with the same letter within the same column are not statistically different $(p>0.05)$ 
Fig. 4 Chromosomal aberrations promoted by $\mathrm{HgCI}_{2}$ (a $\mathrm{MN}$ in interphase $\mathrm{MN}, \mathbf{b}$ fragment in interphase, $\mathbf{c}$ fragment in metaphase, $\mathbf{d}$ sticky chromosome, e vagrant in early telophase, $\mathbf{f}$ vagrant in anaphase (Straight arrows), bridge (dotted arrow), $\mathbf{g}$ unequal distribution of chromatin, $\mathbf{h}$ irregular mitosis, $\mathbf{i}$ nucleus damage)

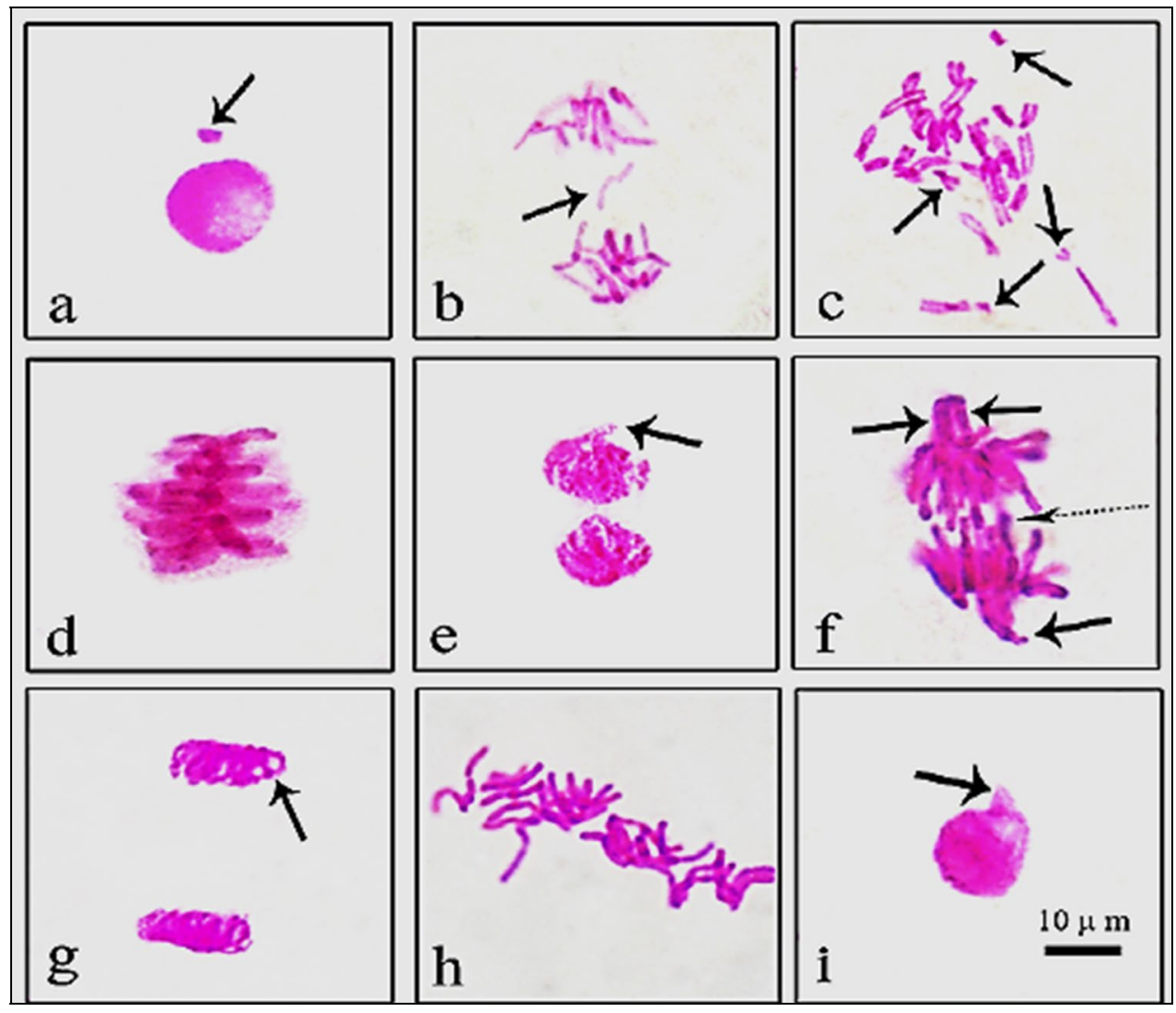

CAT activities and MDA levels compared to $\mathrm{HgCl}_{2}$ administration alone. Decreases in MDA, SOD, and CAT values in $380 \mathrm{mg} / \mathrm{L} \mathrm{GTex}+100 \mathrm{mg} / \mathrm{L} \mathrm{HgCl}_{2}$ application were higher than the $190 \mathrm{mg} / \mathrm{L} \mathrm{GTex}+100 \mathrm{mg} / \mathrm{L} \mathrm{HgCl}_{2}$ group, although they were still above the control levels. While MDA content is an indicator of lipid peroxidation in cells caused by oxidative stress, CAT and SOD are protectors against oxidative stress (Macar 2020). In parallel with the physiological and genotoxic results of this study, application of GTex did not trigger any oxidative stress in A. cepa bulbs. Unlike GTex, application of $\mathrm{HgCI}_{2}$ caused severe oxidative stress in $A$. cepa. $\mathrm{HgCI}_{2}$ administration caused a significant increase in MDA level and abnormality in antioxidant enzyme levels, resulting in deterioration of antioxidant/oxidant balance. $\mathrm{Hg}$ can damage the cells by increasing the ROS level (Ercal et al. 2001). Free radicals generated by $\mathrm{Hg}$ have different effects, but genotoxic effect is the most important one. Lipids are very sensitive to ROS and mercury-induced free radicals cause lipid peroxidation (Rabeh et al. 2019). In the cell membrane, which has a high lipid content, changes occur in membrane structure and permeability due to lipid peroxidation. MDA is a mutagenic product formed as a result of lipid peroxidation. At the end of the normal biochemical process, low levels of MDA can occur in cells and can be removed with the antioxidant system. Increasing MDA level indicates oxidative stress and lipid peroxidation in the cell (Rana et al. 1995; Crespo-López et al. 2009). Oxidative stress caused by mercurial was observed on a variety of organisms such as tomato (Cho and Park 2000), mallard ducks (Hoffman and Heinz 1998), cucumber (Cargnelutti et al. 2006), and human (Marcusson and Jarstrand 1998; Granitzer et al. 2020). In addition, modifying effect of $\mathrm{Hg}$ on SOD and CAT activities in A. cepa was mentioned by other researchers (Subhadra et al. 1991; Fatima and Ahmad 2005). Medicinal plants and their products have protective effects against $\mathrm{Hg}$-induced oxidative stress by raising of endogenous enzymatic and non-enzymatic defense systems (Bhattacharya 2018). With GTex application, a decrease in MDA levels and an improvement in antioxidant/oxidant balance were observed. The decrease in MDA levels is closely related to the radical scavenging activity of GTex. The ability of GTex to scavenge free radicals was determined by previous analyzes in this study. GTex exhibited a significant scavenging effect against superoxide and $\mathrm{H}_{2} \mathrm{O}_{2}$ that cause oxidation in the cell and especially in cell membrane lipids. Especially catechins in GTex content have an important role in scavenging free radicals. Catechins perform their activities with $\mathrm{H}$-donating antioxidant processes, reducing oxidative stress and maintaining the antioxidant balance in the cell. Catechins also have mechanisms that directly or indirectly regulate the expression of enzymatic antioxidants including SOD (Simos et al. 2012). Caffeine, another active 
Table 4 Protective role of GTex against $\mathrm{HgCI}_{2}$-induced meristematic cell damage

\begin{tabular}{|c|c|c|c|c|c|}
\hline Damages & ECD & TCCW & $\mathrm{CCD}$ & FCN & ITT \\
\hline Control & - & - & - & - & - \\
\hline $190 \mathrm{mg} / \mathrm{L}$ GTex & - & - & - & - & - \\
\hline $380 \mathrm{mg} / \mathrm{L}$ GTex & - & - & - & - & - \\
\hline $100 \mathrm{mg} / \mathrm{L} \mathrm{HgCI}{ }_{2}$ & +++ & ++ & ++ & +++ & ++ \\
\hline $190 \mathrm{mg} / \mathrm{L} \mathrm{m} \mathrm{GTex}+100 \mathrm{mg} / \mathrm{L} \mathrm{HgCI}{ }_{2}$ & ++ & + & + & ++ & + \\
\hline $380 \mathrm{mg} / \mathrm{L}$ GTex $+100 \mathrm{mg} / \mathrm{L} \mathrm{HgCI}_{2}$ & + & + & - & + & - \\
\hline
\end{tabular}

${ }^{*} E C D$, epidermis cell damage; $T C C W$, thickening of the cortex cell wall; $C C D$, cortex cell damage; $F C N$, flattened cell nucleus; ITT, indistinct transmission tissue. $(-)$, no damage; $(+)$, little damage; $(++)$, moderate damage; $(+++)$, severe damage ingredient in GTex, also scavenges various radicals such as peroxyl and hydroxyl, thereby reducing oxidative stress in the cell (Demirtaş et al. 2012). In short, the catechin derivatives and caffeine found in GTex allow the protection and continuation of the antioxidant balance that has been disturbed by the mercury.

\section{Anatomical alterations}

Since the roots are the first contact areas with heavy metals, cell damage can be seen easily in the meristematic tissue in the roots. Table 4 shows the severity of meristematic cell damages in GTex and $\mathrm{HgCl}_{2}$ treatments. Meristematic cell damages induced by $\mathrm{HgCI}_{2}$ are presented in Fig. 5. No meristematic cell injury was observed in control, $190 \mathrm{mg} / \mathrm{L}$, and $380 \mathrm{mg} / \mathrm{L}$ GTex treatments. Application of $\mathrm{HgCI}_{2}$ resulted in severe epidermis cell damage (Fig. 5e), moderate thickening of the cortex cell wall (Fig. 5f), moderate cortex cell damage (Fig. 5f), severely flattened cell nucleus (Fig. 5g), and moderate indistinct transmission tissue (Fig. 5h). Severity of all meristematic cell damage types was decreased with increasing GTex doses. Scarce $\mathrm{Hg}$ in the soil tends to accumulate in the root tissue, indicating that the roots act as a barrier to Hg (Patra and Sharma 2000). Roots are more vulnerable than other parts of the plant due to $\mathrm{Hg}$ accumulation. Similar to our findings, Çavuşoğlu et al. (2018) reported meristematic cell damages in $A$. cepa induced by $\mathrm{Hg}$ exposure. In addition, copper-induced injuries in the $A$. cepa root meristem have been reported previously (Macar et al. 2020b; Kalefetoğlu Macar et al. 2020b). The most likely causes of meristematic cell damages are direct attack of ROS arising from Hg-related oxidative imbalance to the macromolecules in the cells as well as cell membrane injuries caused by lipid peroxidation. Results of meristematic cell damages were in line with growth retardation, genotoxicity, and oxidative stress finding of this study. Thanks to its high antioxidant power, GTex prevented root damage by reducing the toxic effects of $\mathrm{Hg}$.

\section{Conclusion}

In conclusion, mitigative and healing capabilities of GTex against $\mathrm{HgCl}_{2}$-induced toxicity revealed with detailed $A$. cepa assay. Although toxicity of $\mathrm{Hg}$ has already been investigated, this is the first work that demonstrated the preventive and restorative role of GTex extract against a dangerous heavy metal in A. cepa. Results of the study clearly exhibit $\mathrm{HgCI}_{2}$ exposure has serious adverse effects on all investigated parameters. On the contrary,
Fig. 5 Meristematic cell damage caused by $\mathrm{HgCI}_{2}$ application (a normal appearance of epidermis cells, $\mathbf{b}$ normal appearance of cortex cells, c normal appearance of nucleus, d normal appearance of transmission tissue, $\mathbf{e}$ epidermis cell damage, $\mathbf{f}$ cortex cell damage (black arrows), thickening of the cortex cell wall (white arrows), $\mathbf{g}$ flattened cell nucleus, $\mathbf{h}$ indistinct transmission tissue)

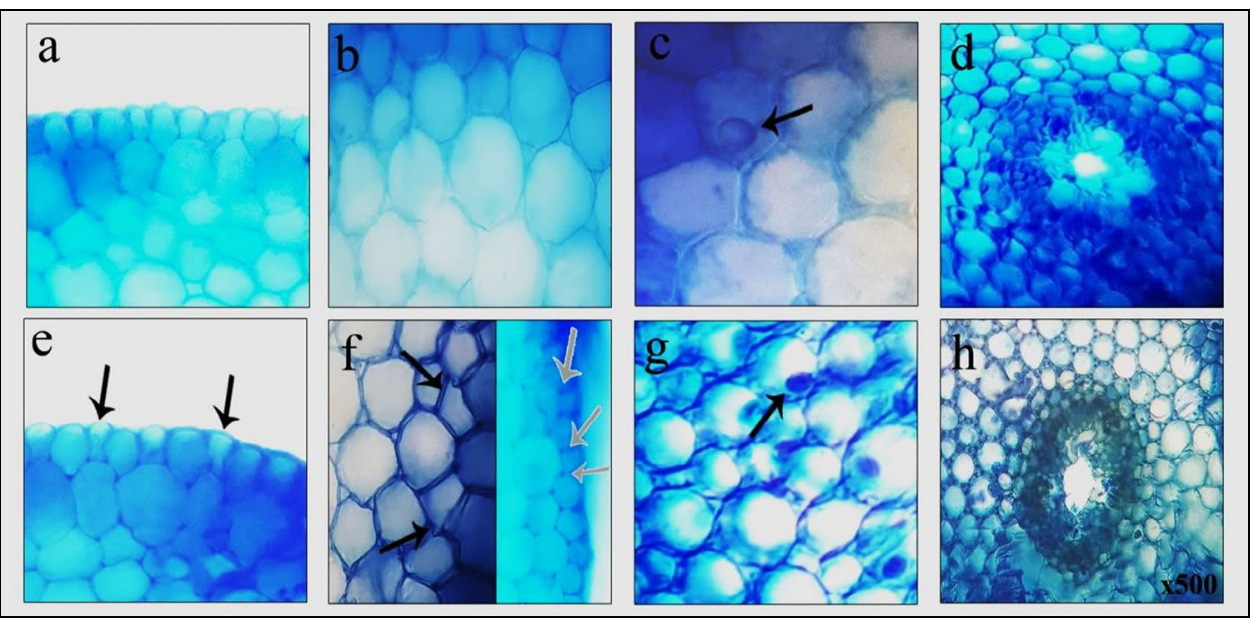


GTex application mitigated and restored the harmful effects of Hg-induced toxicity on all parameters depending on the dose. Results of biochemical parameters pointed that well-known antioxidant power of GTex closely related to alleviation of toxicity caused by Hg. The absence of a negative effect of GTex in this study answered some concerns regarding the use of this product. The overall results of this study provide a reliable starting point for studies investigating the more widespread and diverse use of GTex against toxic substances, especially heavy metals.

As a result, it was determined that $\mathrm{HgCI}_{2}$, which is widely used in industrial sectors and polluting the environment in various ways from these sectors, has a toxic effect on A. cepa. For this reason, the use of $\mathrm{HgCI}_{2}$ in industrial areas should be avoided as much as possible or its contamination should be reduced. Within the scope of the study, it was determined that GTex plays a role in reducing $\mathrm{HgCI}_{2}$ toxicity and the A. cepa test material is a useful biological indicator to observe these effects. A. cepa, a model eukaryotic organism, is very useful in determining the toxic effects of chemical agents in eukaryotes and in detecting agents that will reduce these toxic effects.

Author contribution Dr. Dilek Çavuşoğlu, Dr. Oksal Macar, Dr. Tuğçe Kalefetoğlu Macar, Dr. Kültiğin Çavuşoğlu, and Dr. Emine Yalçın carried out the experimental stages, manuscript preparation, and statistical analysis.

Data availability All data generated or analyzed during this study are included in this published article.

\section{Declarations}

Ethics approval Not applicable.

Consent to participate Not applicable.

Consent for publication All authors whose names appear on the submission approved the version to be published and agree to be accountable for all aspects of the work in ensuring that questions related to the accuracy or integrity of any part of the work are appropriately investigated and resolved.

Competing interests The authors declare no competing interests.

\section{References}

Ajsuvakova OP, Tinkov AA, Aschner M, Rocha JB, Michalke B, Skalnaya MG, Skalny AV, Butnariu M, Dadar M, Sarac I, Aaseth J, Geir B (2020) Sulfhydryl groups as targets of mercury toxicity. Coord Chem Rev 417:213343

Akcan AB, Dursun O (2008) Toxicity of Mercury J Curr Pediatr 6:72-75

Beauchamp C, Fridovich I (1971) Superoxide dismutase: improved assays and an assay applicable to acrylamide gels. Anal Biochem 44:276-287

Beers RF, Sizer IW (1952) A spectrophotometric method for measuring the breakdown of hydrogen peroxide by catalase. J Biol Chem 195:133-140
Bettuzzi S, Gabba L, Cataldo S (2021) Efficacy of a polyphenolic, standardized green tea extract for the treatment of COVID-19 syndrome: a proof-of-principle study. COVID 1(1):2-12

Bhattacharya S (2018) Medicinal plants and natural products can play a significant role in mitigation of mercury toxicity. Interdiscip Toxicol 11(4):247-254

Cabrera C, Giménez R, López MC (2003) Determination of tea components with antioxidant activity. J Agric Food Chem 51(15):4427-4435

Cargnelutti D, Tabaldi LA, Spanevello RM, de Oliveira JG, Battisti V, Redin M, Linares CEB, Dressler VL, Flores EMDM, Nicoloso FT, Morsch VM, Schetinger MRC (2006) Mercury toxicity induces oxidative stress in growing cucumber seedlings. Chemosphere 65(6):999-1006

Çavuşoğlu D (2020) The effects of green tea leaf extract on cytogenetical and physiological parameters of Allium cepa $\mathrm{L}$. exposed to salinity. SAUJS 24(2):338-346

Çavuşoğlu K, Acar A, Yalçın E (2018) Civa (Hg) ağır metal iyonunun Allium cepa L. (soğan)'da teşvik ettiği fizyolojik, sitogenetik ve anatomik değişimlerin araştırılması. DÜBİTED 6(4):887-892

Çavuşoğlu D, Yalçin E, Çavuşoğlu K, Acar A, Yapar K (2021) Molecular docking and toxicity assessment of spirodiclofen: protective role of lycopene. Environ Sci Pollut Res 1-14.

Cho UH, Park JO (2000) Mercury-induced oxidative stress in tomato seedlings. Plant Sci 156(1):1-9

Chong SY, Chiang HY, Chen TH, Liang YJ, Lo YC (2019) Green tea extract promotes DNA repair in a yeast model. Sci Rep 9(1):1-9

Costa S, Utan A, Cervellati R, Speroni E, Guerra MC (2007) Catechins: natural free-radical scavengers against ochratoxin A-induced cell damage in a pig kidney cell line (LLC-PK1). Food Chem Toxicol 45(10):1910-1917

Crespo-López ME, Macêdo GL, Pereira SI, Arrifano GP, PicançoDiniz DL, do Nascimento JLM, Herculano AM, (2009) Mercury and human genotoxicity: critical considerations and possible molecular mechanisms. Pharmacol Res 60(4):212-220

Demirtaş C, Ofluoğlu Demir FE, Hussein A, Paşaoğlu H (2012) Effects of caffeine on oxidant-antioxidant mechanisms in the rat liver. Gazi Med J 23(1):13-18

Ercal N, Gurer-Orhan H, Aykin-Burns N (2001) Toxic metals and oxidative stress. Part I: mechanisms involved inmetal-induced oxidative damage. Curr Top Med Chem 1:529-539

Fatima RA, Ahmad M (2005) Certain antioxidant enzymes of Allium cepa as biomarkers for the detection of toxic heavy metals in wastewater. Sci Total Environ 346(1-3):256-273

Fernandez PL, Martin MJ, Gonzalez AG, Pablos F (2000) HPLC determination of catechins and caffeine in tea. Differentiation of green, black and instant teas. Analyst 125(3):421-425

García-Rodríguez MDC, Carvente-Juárez MM, Altamirano-Lozano MA (2013) Antigenotoxic and apoptotic activity of green tea polyphenol extracts on hexavalent chromium-induced DNA damage in peripheral blood of CD-1 mice: analysis with differential acridine orange/ethidium bromide staining. Oxid Med Cell Longev 486419

Glei M, Pool-Zobel BL (2006) The main catechin of green tea,(-)epigallocatechin-3-gallate (EGCG), reduces bleomycininduced DNA damage in human leucocytes. Toxicol in Vitro 20(3):295-300

Glińska S, Bartczak M, Oleksiak S, Wolska A, Gabara B, Posmyk M, Janas K (2007) Effects of anthocyanin-rich extract from red cabbage leaves on meristematic cells of Allium cepa $\mathrm{L}$. roots treated with heavy metals. Ecotoxicol Environ Saf 68(3):343-350

Gramza A, Pawlak-Lemañska K, Korczak J, Wasowicz E, Rudzinska M (2005) Tea extracts as free radical scavengers. Pol J Environ Stud 14(6):861

Granitzer S, Ellinger I, Khan R, Gelles K, Widhalm R, Hengstschläger M, Zeisler H, Desoye G, Tupova L, Ceckova M, Salzer H, Gundacker C (2020) In vitro function and in situ localization of 
multidrug resistance-associated protein (MRP) 1 (ABCC1) suggest a protective role against methyl mercury-induced oxidative stress in the human placenta. Arch Toxicol 94(11):3799-3817

Grant WF (1982) Chromosome aberration assays in Allium. A report of the U.S. Environmental protection agency gene-tox program. Mutat Res Genet Toxicol Environ Mutagen 99:273-291

Gülçin İ, Huyut Z, Elmastaş M, Aboul-Enein HY (2010) Radical scavenging and antioxidant activity of tannic acid. Arab J Chem $3(1): 43-53$

Hansen JM, Zhang H, Jones DP (2006) Differential oxidation of thioredoxin-1, thioredoxin-2, and glutathione by metal ions. Free Radic Biol Med 40(1):138-145

Hasegawa R, Chujo T, Sai-Kato K, Umemura T, Tanimura A, Kurokawa Y (1995) Preventive effects of green tea against liver oxidative DNA damage and hepatotoxicity in rats treated with 2-nitropropane. Food Chem Toxicol 33(11):961-970

Hemmati V, Garavand F, Khorsidian N, Cacciotti I, Goudarzi M, Chaichi M, Tiwari BK (2021) Impact of cold atmospheric plasma on microbial safety, total phenolic and flavonoid contents, antioxidant activity, volatile compounds, surface morphology, and sensory quality of green tea powder. Food Biosci 101348 .

Hoffman DJ, Heinz GH (1998) Effects of mercury and selenium on glutathione metabolism and oxidative stress in mallard ducks. Environ Toxicol Chem 17(2):161-166

Jaiswal S, Dey R, Bag A (2021) Effect of heavy metal cadmium on cell proliferation and chromosomal integrity in Allium cepa. Natl Acad Sci Lett 1-3.

Jang M, Park R, Park YI, Cha YE, Yamamoto A, Lee JI, Park J (2021) EGCG, a green tea polyphenol, inhibits human coronavirus replication in vitro. Biochem Biophys Res Commun 547:23-28

Jo C, Jeong SM, Kim SY, Park E, Lee SC (2008) Effect of irradiation on the antioxidative and antigenotoxic activities of a green tea leaf and stem extract. Int J Food Sci Technol 43(3):400-405

Kalefetoğlu Macar T, Macar O, Yalçın E, Çavuşoğlu K (2020a) Protective roles of grape seed (Vitis vinifera $\mathrm{L}$.) extract against cobalt (II) nitrate stress in Allium cepa L. root tip cells. Environ Sci Pollut Res 1-10

Kalefetoğlu Macar T, Macar O, Yalçın E, Çavuşoğlu K (2020b) Resveratrol ameliorates the physiological, biochemical, cytogenetic, and anatomical toxicities induced by copper (II) chloride exposure in Allium cepa L. Environ Sci Pollut Res 27(1):657-667

Kamynsky R, Primachenko V, Sokurenko L, Chaikovsky Y (2016) A study of impact of mercury chloride on myocardium in experiment. Georgian Med News 251:64-70

Kaur M, Sharma A, Soodan RK, Chahal V, Kumar V, Katnoria JK, Nagpal AK (2019) Allium cepa root chromosomal aberration assay: a tool to assess genotoxicity of environmental contaminants. In: Sharma A, Kumar M, Kaur S, Nagpal AK (eds) Evaluation of environmental contaminants and natural products: a human health perspective. Bentham Science Publishers, pp 65-93

Kumari K, Chand GB (2021) Acute toxicity assessment of mercury chloride to freshwater air breathing fish Clarias batrachus (Linnaeus, 1758): in vivo study. Agric Sci Dig 41:242-246

Larsen CA, Dashwood RH, Bisson WH (2010) Tea catechins as inhibitors of receptor tyrosine kinases: mechanistic insights and human relevance. Pharmacol Res 62(6):457-464

Liu S, Wang X, Guo G, Yan Z (2021) Status and environmental management of soil mercury pollution in China: a review. J Environ Manage 277:111442

Macar O (2020) Multiple toxic effects of tetraconazole in Allium сера L. meristematic cells. Environ Sci Pollut Res 1-8

Macar O, Kalefetoğlu Macar T, Çavuşoğlu K, Yalçın E (2020a). Determination of protective effect of carob (Ceratonia siliqua L.) extract against cobalt (II) nitrate-induced toxicity. Environ Sci Pollut Res 27(32):40253-40261

Macar O, Kalefetoğlu Macar T, Çavuşoğlu K, Yalçın E (2020b) Protective effects of anthocyanin-rich bilberry (Vaccinium myrtillus
L.) extract against copper (II) chloride toxicity. Environ Sci Pollut Res 27(2):1428-1435

Maiti S, Nazmeen A, da Med N, Patra R, Ghosh TK (2019) Flavonoids green tea against oxidant stress and inflammation with related human diseases. Clin Nutr Exp 24:1-14

Marcusson JA, Jarstrand C (1998) Oxidative metabolism of neutrophils in vitro and human mercury intolerance. Toxicol in Vitro 12(4):383-388

Masek A, Chrzescijanska E, Latos M, Zaborski M, Podsedek A (2017) Antioxidant and antiradical properties of green tea extract compounds. Int J Electrochem Sci 12:6600-6610

Maurya PK, Rizvi SI (2009) Protective role of tea catechins on erythrocytes subjected to oxidative stress during human aging. Nat Prod Res 23(12):1072-1079

Miyagawa C, Wu C, Kennedy DO, Nakatani T, Ohtani K, Sakanaka S, Kim M, Matsui-Yuasa I (1997) Protective effect of green tea extract and tea polyphenols against the cytotoxicity of 1 , 4-naphthoquinone in isolated rat hepatocytes. Biosci Biotechnol Biochem 61(11):1901-1905

Muhammad ZI, Maria KS, Mohammad A, Muhammad S, Zia-UrRehman F, Muhammad K (2015) Effect of mercury on seed germination and seedling growth of mungbean (Vigna radiata (L.) Wilczek). J Appl Sci Environ Manage 19(2):191-199

Mutter J, Naumann J, Schneider R, Walach H, Haley B (2005) Mercury and autism: accelerating evidence? Neuro Endocrinol Lett 26(5):439-446

Natasha, Shahid M, Khalid S, Bibi I, Bundschuh J, Niazi NK, Dumat C (2020) A critical review of mercury speciation, bioavailability, toxicity and detoxification in soil-plant environment: ecotoxicology and health risk assessment. Sci Total Environ 711:134749

Özbolat G, Tuli A (2016) Effects of heavy metal toxicity on human health. AKTD 25(4):502-521

Özkara A, Akyıl D, Eren Y, Erdoğmuş SF (2015) Potential cytotoxic effect of anilofos by using Allium cepa assay. Cytotechnology 67(5):783-791

Öztürk M (2006) Effects of mercury pollution on the environment and health. Ministry of Environment and Forestry, Ankara

Patra M, Bhowmik N, Bandopadhyay B, Sharma A (2004) Comparison of mercury, lead and arsenic with respect to genotoxic effects on plant systems and the development of genetic tolerance. Environ Exp Bot 52(3):199-223

Patra M, Sharma A (2000) Mercury toxicity in plants. Bot Rev 66(3):379-422

Rabeh I, Telahigue K, Bejaoui S, Hajji T, Chouba L, Cafsi EL, MH, Soudani N, (2019) Effects of mercury graded doses on redox status, metallothionein levels and genotoxicity in the intestine of sea cucumber Holothuria forskali. Chem Ecol 35(3):204-218

Rana SVS, Singh R, Verma S (1995) Mercury-induced lipid peroxidation in the liver, kidney, brain and gills of a fresh water fish. Channa Punctatus Japan J Ichthyol 42(3-4):255-259

Roy M, Chakrabarty S, Sinha D, Bhattacharya RK, Siddiqi M (2003) Anticlastogenic, antigenotoxic and apoptotic activity of epigallocatechin gallate: a green tea polyphenol. Mut Res-Fund Mol M 523:33-41

Ruch RJ, Cheng SJ, Klaunig JE (1989) Prevention of cytotoxicity and inhibition of intercellular communication by antioxidant catechins isolated from Chinese green tea. Carcinogenesis 10(6):1003-1008

Şahin H, Özdemir F (2006) Effect of green tea on health. Turkey $9^{\text {th }}$ Food Congress 9:219-222

Sharma PC, Gupta PK (1982) Karyotypes in some pulse crops. Nucleus 25:181-185

Sharma S, Nagpal A, Vig AP (2012) Genoprotective potential of Brassica juncea (L.) Czern. against mercury-induced genotoxicity in Allium cepa L. Turk J Biol 36(6):622-629

Shirakami Y, Shimizu M (2018) Possible mechanisms of green tea and its constituents against cancer. Molecules 23(9):2284 
Simos YV, Verginadis II, Toliopoulos IK, Velalopoulou AP, Karagounis IV, Karkabounas SC, Evangelou AM (2012) Effects of catechin and epicatechin on superoxide dismutase and glutathione peroxidase activity, in vivo. Redox Rep 17(5):181-186

Subhadra AV, Nanda AK, Behera PK, Panda BB (1991) Acceleration of catalase and peroxidase activities in Lemna minor L. and Allium cepa $\mathrm{L}$. in response to low levels of aquatic mercury. Environ Pollut 69(2-3):169-179

Suzuki Y, Miyoshi N, Isemura M (2012) Health-promoting effects of green tea. Proc Jpn Acad Ser B 88(3):88-101

Telahigue K, Rabe I, Bejaoui S, Hajji T, Nechi S, Chelbi E, El Cafsi M, Soudani N (2020) Mercury disrupts redox status, up-regulates metallothionein and induces genotoxicity in respiratory tree of sea cucumber (Holothuria forskali). Drug Chem Toxicol 43(3):287-297

UNEP (2013) Mercury - time to act. https://wedocs.unep.org/bitstream/ handle/20.500.11822/27436/mercury_timetoact.pdf?sequence $=$ 1 \&isAllowed $=\mathrm{y}$. Accessed 3 June 2021

Unyayar S, Celik A, Cekic FO, Gozel A (2006) Cadmium-induced genotoxicity, cytotoxicity and lipid peroxidation in Allium sativum and Vicia faba. Mutagenesis 21:77-81
Xia Z, Duan X, Tao S, Qiu W, Liu D, Wang Y, Wei S, Wang B, Jiang Q, Lu B, Song Y, Hu X (2013) Pollution level, inhalation exposure and lung cancer risk of ambient atmospheric polycyclic aromatic hydrocarbons (PAHs) in Taiyuan, China. Environ Pollut 173:150-156

Yalçın E, Macar O, Kalefetoğlu Macar T, Çavuşoğlu D, Çavuşoğlu K (2021) Multi-protective role of Echinacea purpurea L. water extract in Allium cepa L. against mercury (II) chloride. Environ Sci Pollut Res 1-9.

Zhu Y, Lin H, Feng Q, Zhao B, Lan W, Li T, Xue B, Li M, Zhang, Z. (2021). Sulfhydryl-modified $\mathrm{SiO}_{2}$ cryogel: a pH-insensitive and selective adsorbent for efficient removal of mercury in waters. Colloids Surf A Physicochem Eng Asp 617:126382

Publisher's note Springer Nature remains neutral with regard to jurisdictional claims in published maps and institutional affiliations. 